\title{
Nutrient Utilization in Yankasa Rams Fed Crop Residue Supplemented With Xylanase and Glucanase Combinations
}

Jacob Jafiya Millam ( $\boldsymbol{\sim}$ jacobjafiya@gmail.com )

Adamawa State University https://orcid.org/0000-0002-6654-8728

Augustine Waja

Adamawa State University

Hyellafiya Papas

Adamawa State University

\section{Research}

Keywords: Digestibility, Exogenous fibrolytic enzymes, Feed intake, Nitrogen balance, Supplementation

Posted Date: December 17th, 2020

DOl: https://doi.org/10.21203/rs.3.rs-129118/v1

License: (c) (i) This work is licensed under a Creative Commons Attribution 4.0 International License.

Read Full License 


\section{Abstract}

Background: There is less information in Nigeria with regard the understanding of the use of exogenous enzymes widely used in monogastric diets in ruminant's rations. The study evaluated the effects of supplementing xylanase and glucanase in combination in rations of Yankasa rams. Sixteen yearling Yankasa rams (average $21 \mathrm{~kg}$ ) were used. Four treatments were evaluated: control (without enzyme combination), 50:50, 75:25 and 25:75 xylanase-glucanase combinations denoted as $T_{1}, T_{2}, T_{3}$, and $T_{4}$ respectively. The basal roughage was cowpea husk and sorghum husk. The feeding trial was conducted using complete randomize design.

Results: There were differences $(\mathrm{p}<0.05)$ with regard to nutrient intake and total digestibility coefficient except crude protein and nitrogen free extract digestibility $(p>0.05)$. The intake and digestibility increased with supplementation of xylanase and glucanase combination at 25:75 ratio respectively. It increased DM intake by $211.90 \mathrm{~g} / \mathrm{d}$, DM digestibility by $17.73 \%$, ADF digestibility by $1.17 \%$ and NDF digestibility by $1.02 \%$. The nitrogen balance in the body did not increase ( $p>0.05)$ with supplementation of $50: 50$ xylanase-glucanase combination. The efficiency of nitrogen utilization did not differ between the control and 50:50 xylanase-glucanase combination.

Conclusion: The combination of xylanase and glucanase at ratio 25:75 respectively improved nutrient intake and digestibility but did not influence nitrogen utilization.

\section{Background}

The scarcity of feeds is one of the major constraint to livestock production in the northern region of Nigeria (1). These are due to the shortage \& cost of conventional feeds (consumed by humans) and the crop residues (consumed by a large number of animals) available are of poor nutritional status. These poor quality roughages comprise a huge part of the feed readily available and its consumption results to low plane of nutrition with attendant low productivity of the country's indigenous animals (2). Even though these crop residues are available to the ruminants and are produced in large quantity annually (most of them comes as threshing by-product), little quantity is used as feeds. The rest are usually left on farm to rot or thrown away as waste (3).

These problems has directed research efforts towards harnessing and enhancing the utilization of these abundant arable crop residues. Therefore, the concept of matching available/abundant feed resources with the production of ruminants has consequently intensified research into the evaluation of crop residues for feeding livestock rather than discarding it as waste (4). Similarly, since animal performance on these crop residues are poor, one of the ways to improve the quality of these crop residues is through enzyme supplementation (5). Commercial fibrolytic enzymes such as xylanase and glucanase have been used in monogastric rations over the years. Few trials have tested its efficacy in ruminates especially in Nigeria (6). Such exogenous enzymes have been tried in other regions to have recorded improved weight gain, feed efficiency, digestibility and rumen degradability (7-13). Therefore, the aim of this study was to 
determine the effects of using xylanase and glucanase designed for use in monogastric rations, could be used as feed enzyme additive for Yankasa rams to enhance nutrient utilization.

\section{Methods}

This experiment was carried out at the Small Ruminant Unit of Adamawa State University Teaching and Research Farm, Mubi. All research protocols and use of animals were approved by Ahmadu Bello University Committee of Animal Use and Care. It certifies that the procedures adhere to the International standards on animal use and practice.

The feed ingredients [cowpea husk, sorghum husk, local brewer's residue (burukutu waste), maize offal, bone meal and salt] for the experiment were obtained from TIKE cattle market, Mubi South Local Government Area, Adamawa State. The enzymes (xylanase and glucanase) were purchased from a local vendor in Kaduna, Kaduna State. The vendor obtained it from RONOZYME® MultiGrain (MG), DSM Nutritional Products Ltd, Switzerland; xylanase (endo-1, 4- $\beta$-xylanase; EC 3.2.1.8) and glucanase (endo-1, 3(4)- $\beta$-glucanase; EC 3.2.1.6 and endo-1, 4- $\beta$-glucanase; EC 3.2.1.4).

The study evaluated the following dietary treatments: $T_{1}$, control (no supplementation); $T_{2}$, with 50:50 ratio of xylanase-glucanase combination; $T_{3}$, with 75:25 ratio of xylanase-glucanase combination; $T_{4}$, with 25:75 ratio of xylanase-glucanase combination (Table 1). The difference in enzyme combination makes the difference in ration. The enzymes were incorporated into the rations at the rate of $100 \mathrm{~g}$ per tonne of feed (manufacturer's recommendation). The ration was formulated using computer method (least cost ration formulation software). 
Table 1

Dietary composition of the experimental rations

\begin{tabular}{|lllll|}
\hline Parameters (\%) & $\mathrm{T}_{1}$ & $\mathrm{~T}_{2}$ & $\mathrm{~T}_{3}$ & $\mathrm{~T}_{4}$ \\
\hline Cowpea husk & 30.00 & 30.00 & 30.00 & 30.00 \\
\hline Sorghum husk & 30.00 & 30.00 & 30.00 & 30.00 \\
\hline Maize offal & 25.40 & 25.40 & 25.40 & 25.40 \\
\hline Local brewers residue & 12.60 & 12.60 & 12.60 & 12.60 \\
\hline Bone meal & 1.50 & 1.50 & 1.50 & 1.50 \\
\hline Salt & 0.50 & 0.50 & 0.50 & 0.50 \\
\hline Enzyme combination & 0.00 & 0.01 & 0.01 & 0.01 \\
\hline Total & 100.00 & 100.00 & 100.00 & 100.00 \\
\hline Chemical analysis (\%) & & & & \\
\hline Energy (kcal/kg) & 2994.30 & 2994.30 & 2994.30 & 2994.30 \\
\hline Dry matter & 94.50 & 94.50 & 94.50 & 94.50 \\
\hline Crude protein & 18.56 & 18.56 & 18.56 & 18.56 \\
\hline Ether extract & 6.51 & 6.51 & 6.51 & 6.51 \\
\hline Ash & 6.80 & 6.80 & 6.80 & 6.80 \\
\hline Nitrogen free extract & 50.13 & 50.13 & 50.13 & 50.13 \\
\hline Acid detergent fibre & 51.43 & 51.43 & 51.43 & 51.43 \\
\hline Neutral detergent fibre & 46.55 & 46.55 & 46.55 & 46.55 \\
\hline Enzyme combination: the combination of both xylanase and glucanase at 50:50, & & & 75.25 and $25: 75$ \\
\hline levels of inclusion to makeup 10 g. & & & & \\
\hline
\end{tabular}

The rations were mixed on a concrete floor by use of shovel, then bagged and kept safe for the experiment. A sample from the formulated ration was collected, and its proximate compositions was determined using the procedures described by (14). Neutral detergent fibre (NDF) and Acid detergent fibre (ADF) was determined by the methods of (15).

Sixteen yearling Yankasa rams (Ovis aries) with an average initial weight of $21 \mathrm{~kg}$ were used in this experiment. The rams were purchased from TIKE cattle market. Prior to the experiment, the rams were adapted to the experimental conditions for 2 weeks. While adjusting to the environment, the rams were fed voluntarily and water ad lib, given long-lasting antibiotics (Oxytetracycline LA®) and ivermectin 
(Ivomec $\AA$ ) against bacterial infection, ecto- and endo-parasites respectively. After the adaptation period was over, the feeding trial commenced.

The rams were housed in a well ventilated, individual enclosures $(2 \times 2 \mathrm{~m})$ with concrete floor and equipped with individual feeders and water troughs. Theses stalls were washed properly and disinfected a week before the commencement of the feeding trial.

The rations were assigned randomly to each group of rams using Completely Randomise Design with 4 rams per treatment. The rams were fed at $3 \%$ body weight and water was offered ad libitum. The total ration for a day was separated into two portions of equal weight and supplied to the animals at 8:00 $\mathrm{h}$ and 14:00 h. Feed offered and left over was measured daily using electronic kitchen scale (WH-B05). The left over is deduced from the feed offered to compute the feed intake daily until the end of the feeding trial. The feeding trial lasted for 12 weeks.

For the digestibility trial, the rams were housed in individual metabolic cages according to the procedures of (16). The metabolic cages was designed for separate collection of urine and faeces. Twenty one days was used as adjustment period on the crates, while seven days was for the collection of urine and faeces. Daily faeces and urine voided out by each ram was collected and measured. At the end of the collection period, the total faeces was then bulked and representative aliquot $(10 \%)$ sample was collected for chemical analysis. Total urine collection was made over urine container acidified with sulphuric acid; $10 \mathrm{ml} 0.1 \mathrm{~N} \mathrm{H}_{2} \mathrm{SO}_{4}$ (16). This was to avoid nitrogen loss. The urine was measured and $20 \mathrm{ml}$ aliquot were collected for nitrogen analysis at the Lab. The nitrogen was analysed using the Kjeldahl method of nitrogen analysis (14).

Nutrient intake and digestibility coefficient of the experimental rations was calculated using the methods described by (17). Nitrogen retention was computed as the difference between nitrogen intake and nitrogen losses (urine and faeces) while nitrogen as percentage of intake was calculated from the nitrogen retention expressed as a percentage of nitrogen intake.

All statistical procedure were carried out and analysed according to PROC GLM procedures of (18). The effect of treatment means were tested at probability level of $95 \%(p<0.05)$ and significant effects were compared using Duncan Multiple Range Test.

\section{Results And Discussion}

\section{Intake and digestibility}

There were differences $(p<0.05)$ among treatments with regards to all parameters measured (average daily feed intake, ADFl; dry matter intake, $\mathrm{DMl}$; crude protein intake, $\mathrm{CPl}$; nitrogen free extract intake, NFEl; acid detergent fibre intake, ADFI and neutral detergent fibre intake, NDFI) for nutrient intake (Table 2). $\mathrm{T}_{4}$ (ADFI, $1239.70 \mathrm{~g} ; \mathrm{DMl}, 1171.50 \mathrm{~g}$; CPI, $230.09 \mathrm{~g}$; NFEl, $621.50 \mathrm{~g}$; NDFI, $637.60 \mathrm{~g}$, ADFI, $577.10 \mathrm{~g}$ ) was observed to be higher statistically $(p<0.05)$ for all the parameters compared to other treatments. 
Table 2

Nutrient intake in Yankasa rams fed experimental diets

\begin{tabular}{|lccccc|}
\hline Parameters (g) & $\mathrm{T}_{1}$ & $\mathrm{~T}_{2}$ & $\mathrm{~T}_{3}$ & $\mathrm{~T}_{4}$ & SEM \\
\hline Average daily feed intake & $1015.40^{\mathrm{b}}$ & $976.80^{\mathrm{b}}$ & $969.50^{\mathrm{b}}$ & $1239.70^{\mathrm{a}}$ & 94.99 \\
\hline Dry matter intake & $959.60^{\mathrm{b}}$ & $923.00^{\mathrm{b}}$ & $916.20^{\mathrm{b}}$ & $1171.50^{\mathrm{a}}$ & 89.77 \\
\hline Crude protein intake & $188.46^{\mathrm{b}}$ & $181.29^{\mathrm{b}}$ & $179.95^{\mathrm{b}}$ & $230.09^{\mathrm{a}}$ & 17.63 \\
\hline NFE intake & $509.00^{\mathrm{b}}$ & $489.60^{\mathrm{b}}$ & $486.00^{\mathrm{b}}$ & $621.50^{\mathrm{a}}$ & 47.62 \\
\hline Neutral detergent fibre intake & $522.20^{\mathrm{b}}$ & $502.30^{\mathrm{b}}$ & $498.60^{\mathrm{b}}$ & $637.60^{\mathrm{a}}$ & 48.85 \\
\hline Acid detergent fibre intake & $472.70^{\mathrm{b}}$ & $454.70^{\mathrm{b}}$ & $451.30^{\mathrm{b}}$ & $577.10^{\mathrm{a}}$ & 44.22 \\
\hline $\begin{array}{l}\text { ab: Means with different superscript are significantly different, NFE: nitrogen free intake, SEM: } \\
\text { standard error of means }\end{array}$ & & & & & \\
\hline
\end{tabular}

Increased nutrient intake is an important factor for improved productivity in and utilization of feed by ruminants (19) which may be associated with some factors such as the palatability of the feed, low fibre fraction etc. (20). This translates to the reason which may have brought about this results. High feed intake as observed with the rams receiving 25:75 xylanase-glucanase combination was an indicator that the rams ate the ration due to the taste or smell (21), and consequently influence the prehension and intake frequency of the rams (22). Similarly, the increased nutrient intake may be due to the ration having less lignified cell wall tissues as a result of enzyme supplementation. This decreases ration retention time in the rumen (23). The improvement may have been associated with the enzyme activity that was aimed at enhancing the fibre hydrolysis (5). The results obtained here differ from those reported by several authors who studied the use of various enzyme complex and discovered that its supplementation did not affect nutrient intake in sheep $(9,24,25)$.

Statistical influence $(\mathrm{p}<0.05)$ was observed in all parameters measured for digestibility coefficient (Table 3) except crude protein and nitrogen free extract $(p>0.05)$. $T_{4}$ was observed to have improved dry matter (73.01\%), acid detergent fibre, ADF (65.94\%) and neutral detergent fibre, NDF (79.82\%) compared to other treatments. 
Table 3

Nutrient digestibility of experimental diets in Yankasa rams

\begin{tabular}{|llllll|}
\hline Parameters (\%) & $\mathrm{T}_{1}$ & $\mathrm{~T}_{2}$ & $\mathrm{~T}_{3}$ & $\mathrm{~T}_{4}$ & SEM \\
\hline Dry matter & $55.28^{\mathrm{b}}$ & $60.53^{\mathrm{b}}$ & $62.28^{\mathrm{b}}$ & $73.01^{\mathrm{a}}$ & 5.16 \\
\hline Crude protein & 94.04 & 94.85 & 95.75 & 95.80 & 2.15 \\
\hline Ether extract & $97.68^{\mathrm{a}}$ & $96.96^{\mathrm{b}}$ & $97.4^{\mathrm{ab}}$ & $97.95^{\mathrm{a}}$ & 0.25 \\
\hline Ash & $66.59^{\mathrm{a}}$ & $56.83^{\mathrm{b}}$ & $61.31^{\mathrm{ab}}$ & $68.76^{\mathrm{a}}$ & 4.55 \\
\hline Nitrogen free extract & 75.85 & 76.06 & 75.75 & 76.65 & 0.86 \\
\hline Acid detergent fibre & $64.7^{\mathrm{c}}$ & $65.14^{\mathrm{b}}$ & $65.09^{\mathrm{bc}}$ & $65.94^{\mathrm{a}}$ & 0.16 \\
\hline Neutral detergent fibre & $78.80^{\mathrm{c}}$ & $79.39^{\mathrm{b}}$ & $78.63^{\mathrm{c}}$ & $79.82^{\mathrm{a}}$ & 0.20 \\
\hline abc: Means of different superscript are significantly different, SEM: standard error of means \\
\hline
\end{tabular}

Improved DM, ADF and NDF observed in this study might be as a result of enzyme supplementation (5). These was an indication that the use of 25:75 xylanase-glucanase combination in the ration was successful in improving the digestibility of the crop residues within the gut of the rams. The results was consistent with the works of various authors who reported that exogenous enzymes supplementation in fibrous ration increased fibre digestibility in sheep (26-29). These positive improvements associated with enzyme combination may have resulted from enhanced colonization of feed by increasing the number of ruminal fibrolytic microbes (30), non-fibrolytic microbes (31), increased rate of fibre degradation in the rumen (28), increased rumen microbial protein synthesis (32) and total tract digestibility (33). However, the increased digestion of the fibre fraction (ADF and NDF) in the 25:75 xylanase-glucanase combination compared to the control may also be related to reduced digesta viscosity (34); altered ruminal fermentation (33) or reduction of rumen physical fill over time which will consequently increase nutrient intake (Table 2, Salem et al., 2011).

\section{Nitrogen utilization}

The results records no statistical $(\mathrm{p}<0.05)$ difference among treatments for nitrogen intake and urine nitrogen (Table 4). Nitrogen losses was relatively higher in $T_{4}(0.61 \mathrm{~g} / \mathrm{d})$, it might be attributed to higher loss of nitrogen in the faeces. 
Table 4

Nitrogen balance in Yankasa rams fed experimental diets

\begin{tabular}{|llllll|}
\hline Parameters $(\mathbf{g} / \mathbf{d})$ & $\mathrm{T}_{\mathbf{1}}$ & $\mathrm{T}_{\mathbf{2}}$ & $\mathrm{T}_{\mathbf{3}}$ & $\mathrm{T}_{\mathbf{4}}$ & SEM \\
\hline Nitrogen intake & 2.97 & 2.97 & 2.97 & 2.97 & 0.00 \\
\hline Faecal nitrogen & $0.21^{\mathrm{b}}$ & $0.22^{\mathrm{b}}$ & $0.30^{\mathrm{a}}$ & $0.31^{\mathrm{a}}$ & 0.01 \\
\hline Urine nitrogen & 0.29 & 0.30 & 0.30 & 0.30 & 0.01 \\
\hline Nitrogen losses & $0.50^{\mathrm{c}}$ & $0.51^{\mathrm{b}}$ & $0.60^{\mathrm{a}}$ & $0.61^{\mathrm{a}}$ & 0.01 \\
\hline Nitrogen absorbed & $2.76^{\mathrm{a}}$ & $2.76^{\mathrm{a}}$ & $2.67^{\mathrm{b}}$ & $2.66^{\mathrm{b}}$ & 0.01 \\
\hline Nitrogen retained/balance & $2.47^{\mathrm{a}}$ & $2.46^{\mathrm{a}}$ & $2.37^{\mathrm{b}}$ & $2.36^{\mathrm{b}}$ & 0.01 \\
\hline Nitrogen balance as \% of intake (\%) & $83.27^{\mathrm{a}}$ & $82.92^{\mathrm{a}}$ & $79.66^{\mathrm{b}}$ & $79.44^{\mathrm{b}}$ & 0.41 \\
\hline ab: Means of difference superscript are significantly different, SEM: standard error of means, \\
\hline
\end{tabular}

Nitrogen obtained from the ration consumed by an animal is lost through urine (about $90 \%$ ) and through faeces (about 10\%). In a situation where the losses in faeces is high, it may lead to high nitrogen loss (36). Literatures point out that the major reason which affects the loss of nitrogen through faeces is the forage: concentrate ratio since a high level of concentrate in the diet results in an increased rate of passage which consequently increases nitrogen loss through the activities of the microbes $(17,37,38)$. Hence, the absence of any significant effect for urine nitrogen may also be explained by forage: concentrate ratio of being same (60: 40$)$ in the treatments. The absence of effects may also be due to the fact of the experimental ration been isonitrogenous. The nutritional demands of ruminants highlights the synchronization between protein and dietary carbohydrates in the rumen to maximize microbial synthesis, thereby reducing nitrogen loss through urine (39).

The higher nitrogen absorbed $\left(2.76 \mathrm{~g} / \mathrm{d}\right.$ for both $T_{1}$ and $\left.T_{2}\right)$ and nitrogen retained $\left(T_{1}, 2.47 \mathrm{~g} / \mathrm{d} ; \mathrm{T}_{2}\right.$, $2.46 \mathrm{~g} / \mathrm{d}$ ) was not influenced $(\mathrm{p}<0.05)$ by supplementing the ration with xylanase and glucanase at 50:50 combination because they are statistically same. Nitrogen retention is often referred as a good method of estimating the quantity of nitrogen available for body tissue deposition (39). This is an indication that the diets were able to present adequate levels of nitrogen (Table 1). Increased nitrogen retained/balance is associated with higher urea production in the liver and lower excretion in the urine (40).

The nitrogen balance as percentage of intake $\left(T_{1}, 83.27 \% ; T_{2}, 82.92 \%\right)$ was not influenced $(p<0.05)$ by xylanase and glucanase supplementation at 50:50 combination. Thus, the positive nitrogen balance as percentage of intake noted in all the treatments indicates that there was no excessive loss of nitrogenous compounds during the trial (39). This confirms that the fraction of protein in the ration was adsorbed 
efficiently by the animals (41). Also, this positive balance is an indication that the protein and energy demands (Table 1 ) of the rams were satisfied most likely and there was protein retention in the body of the rams thereby avoiding weight loss (42).

\section{Conclusion}

The supplementation of Yankasa rams fed crop residues with xylanase and glucanase combinations can increase nutrient intake, nutrient digestibility, but may not influence increased nitrogen retention. The improvement for the nutrient intake and digestibility might be as a result of the combination of xylanase and glucanase at a ratio of $25: 75$ respectively.

\section{Abbreviations}

DM: dry matter; ADF: acid detergent fibre; NDF: neutral detergent fibre; DSM: Dutch State Mines; EC: enzyme commission number; PROC GLM: generalised linear model procedure; DMI: dry matter intake; CPI: crude protein intake; NFEl: nitrogen free extract intake; ADFI: acid detergent fibre intake; NDFI: neutral detergent fibre intake.

\section{Declarations}

\section{Ethics approval:}

All research protocols and use of animals were approved by Ahmadu Bello University Committee of Animal Use and Care. It certifies that the procedures adhere to the International standards on animal use and practice.

\section{Consent for publication:}

Not applicable

\section{Availability of data and materials:}

the authors don't really understand what is been referred here.

\section{Competing interests:}

The authors declare that they have no competing interests.

\section{Funding:}

The source of funds that bankrolled this research was personal.

Author's contributions: 
JJM, conceived the study, performed the statistical analysis, made major contributions to draft of manuscript, and coordinated the research group. AW and HP carried out the experimental trial, and helped draft the manuscript. All authors read and approved the final manuscript.

\section{Acknowledgments:}

The authors thank the Animal Nutrition Laboratory of the Department of Animal Production, Adamawa State University-Mubi, and its technician - Mr. Yahaya Baba Kiri for carrying out the chemical analysis reported in this experiment.

\section{References}

1. Akinfemi A, Adua MM, Adu OA. Evaluation of nutritive values of tropical feed sources and byproducts using in vitro gas production technique in ruminant animals. Emirate $\mathrm{J}$ Food Agric [Internet]. 2012;24(4):348-53. Available from: http://ejfa.info/

2. Abdel Hameed AA, Fedel Elseed AM, Salih AM. Growth Performance and Rumen Fermentation of Lambs Fed Untreated or Urea Treated Groundnut Hull with Different Protein Sources. J Anim Prod Adv [Internet]. 2013 [cited 2014 Aug 2];3(3):86-96. Available from: http://www.scopemed.org/? $\mathrm{mno}=34263$

3. Millam JJ, Kosontyav J, Mohammed ID, Abbaya HY, Bello SS, John PA. Development of feeding regimes with some crop residues: maize offal, cowpea husk, poultry litter and groundnut haulms in a semi-arid environment of Nigeria. Niger J Anim Sci. 2018;20(3):213-22.

4. Otaru SM, Adamu AM, Ehoche OW, Makun HJ. Effects of varying the level of palm oil on feed intake, milk yield and composition and postpartum weight changes of Red Sokoto goats. Small Rumin Res [Internet]. 2011;96(1):25-35. Available from: http://dx.doi.org/10.1016/j.smallrumres.2010.11.004

5. Beauchemin KA, Colombatto D, Morgavi DP, Yang WZ. Use of exogenous fibrolytic enzymes to improve feed utilization in ruminants. J Anim Sci. 2012;81:E37-47.

6. Millam JJ, Joel M, Eli BA. Xylanase and glucanase supplementation on growth performance and blood profile of Yankasa rams fed crop residue. J Anim Sci Vet Madicine. 2020;5(5):166-72.

7. Yang HE, Son YS, Beauchemin KA. Effects of Exogenous Enzymes on Ruminal Fermentation and Degradability of Alfalfa Hay and Rice Straw. Asian-Australasian J Anim Sci. 2011;24(1):56-64.

8. Bhasker TV, Nagalakshmi D, Rao DS. Development of appropriate fibrolytic enzyme combination for maize stover and its effect on rumen fermentation in sheep. Asian-Australasian J Anim Sci [Internet]. 2013 Jul;26(7):945-51. Available from: http://www.pubmedcentral.nih.gov/articlerender.fcgi? artid $=4093493 \&$ tool $=$ pmcentrez\&rendertype $=$ abstract

9. Torres N, Mendoza GD, Barcena R, Loera O, Gonzalez S. Effects of various fibrolytc enzyme extracts on digestibility and productive performance of lambs fed a forage-based diet. Anim Nutr Feed Technol. 2013;13(3):381-9. 
10. Menezes-Blackburn D, Greiner R. Enzymes used in animal feed: Leading technologies and forthcoming developments. In: Cirillo G, Spizzirri UG, Lemma F, editors. Functional Polymers in Food Science. UK: Scrivener Publishing LLC; 2015. p. 47-73.

11. Almaraz I, Gonzalez SS, Pinos-Rodriguez JM, Miranda LA. Effects of exogenous fibrolytic enzymes on in sacco and in vitro degradation of diets and on growth performance of lambs. Ital J Anim Sci. 2016;9:6-10.

12. Norovsambuu T, Chuluunbaatar U, Otgonjargal A, Munkhnasan T, Nicholas EO. Effects of exogenous cellulase and xylananse enzyme preparations on feed intake, nutrient digestibility, growth and economics of rearing Mongolian lambs. J Agric Rural Dev Trop Subtrop. 2017;1(118):1612-30.

13. Thammiah V, Samanta AK, Senani S, Sridhar M. Scope of exogenous enzymes in enhancing ruminant productivity. J Dairy, Vet Anim Res. 2017;5(2):67-72.

14. Association Of Analytical Chemist (AOAC). Official Method of Analysis. 18th ed. Maryland, USA: AOAC International; 2011. 25 p.

15. Van Soest PJ, Robertson JB, Lewis BA. Methods of dietary fibre, neutral detergent fibre and nonstarchy polysaccharide in relation to animal nutrition. J Dairy Sci. 1991;74:3583-97.

16. Osuji PO, Nsahlai I V, Khalili H. Feed Evaluation. ILCA manua. Addis Ababa, Ethiopia: ILCA (International Livestock Centre for Africa); 1993. 40 p.

17. McDonald P, Edwards RA, Greenhalgh JFD, Morgan CA, Sinclair LA, Wilkinson RG. Animal Nutrition. Seventh. Morgan CA, Greenhalgh JFD, Sinclair LA, Wilkinson RG, editors. Harlow, England: Prentice Hall; 2010. 714 p.

18. Statistical Analysis Systems (SAS). Statistical package for analyis. North Carolina, USA: Statistical Analysis Systems Institute, Cary; 2002. p. 27.

19. Jiwuba PC, Ikwunze K, Ume SI, Nsidinanya NO. Performance, apparent nutrient digestibiblity and cost benefit of West African Dwarf goats fed dietary levels of Moringa oleifera leaf meal. J Adv Biol Biotechnol. 2016;8(3):1-9.

20. Rahman MM, Abdullah R Bin, Khadijah WEW, Nakagawa T, Akashi R. Feed intake and growth performance of goats fed with Napier grass and oil palm frond supplemented with soya waste. $\mathrm{J}$ Appl Anim Res [Internet]. 2015;43(3):256-60. Available from: http://dx.doi.org/10.1080/09712119.2014.963095

21. TheCattleSite. Importance of Forage Quality [Internet]. Global Ag Media. 2019 [cited 2020 Dec 6]. Available from: http://www.thecattlesite.com/articles/2232/importance-of-forage-quality/

22. Yahya MM, Midau A, Hamdalla S, Abdulrahman BS, Saidu MA. Effects of pre-grazing supplementation of maize offal and cowpea husk on the performance of Red Sokoto goats. Niger $\mathrm{J}$ Anim Sci Technol. 2020;3(2):191-6.

23. Wadhwa M, Bakshi MPS. Utilization of fruit and vegetable waste as livestock feed and as substrates for generation of other value-added products. Makkar HPS 6., editor. Rome, Italy: Food and Agricultural Organisation (FAO); 2013. 65 p. 
24. Varlyakov I, Grigorova N, Slavov T. Effects of Hostazyme C 100 on growth performance and some haematlogical and ethological indexes of yearling rams. Bulg J Agric Sci. 2010;16:659-64.

25. Bueno AL, Martínez GDM, García PAH, García JAM, Pérez FXP. Evaluation of High Doses of Exogenous Fibrolytic Enzymes in Lambs Fed an Oat Straw Based Ration. Anim Nutr Feed Technol. 2013;13:355-62.

26. Meale SJ, Beauchemin KA, Hristov AN, Chaves A V., McAllister TA. Board-Invited Review: Opportunities and challenges in using exogenous enzymes to improve ruminant production. $J$ Anim Sci [Internet]. 2014;92:427-442. Available from: http://www.journalofanimalscience.org/content/92/2/427\%0Awww.asas.org

27. Sujani S, Seresinhe RT. Exogenous enzymes in ruminant nutrition: A review. Asian J Anim Sci. 2015;9(3):85-99.

28. Valdes KI, Salem AZM, Lopez S, Alonso MU, Rivero N, Elighandouri MMY, et al. Influence of exogenous enzymes in presence of Salix babylonica extract on digestibility , microbial protein synthesis and performance of lambs fed maize silage. J Agric Sci [Internet]. 2015;153:732-42. Available from: https://www.cambridge.org/core

29. Salem AZM, Gado HM, Colombatto D, Elghandour MMY. Effects of exogenous enzymes on nutrient digestibility , ruminal fermentation and growth performance in beef steers. Livest Sci [Internet]. 2013;154:69-73. Available from: www.elsevier.com/locate/livsci\%0AEffects

30. Morgavi DP, Nsereko VL, Rode LM, Beauchemin KA, McAllister M, Wang Y. A Trichoderma feed enzyme preparation enhances adhesion of Fibrobacter succinogenes to complex substrates but not to pure cellulose. In: Proceedings of the 25th Conference on Rumen Function, Chicago. Illinois, US; 2000.

31. Colombatto D, Mould FL, Bhatt MK, Morgavi DP, Beauchemin KA, Owen E. Influence of fibrolytic enzymes on the hydrolysis and fermentation of pure cellulose and xylan by mixed ruminal microorganisms in vitro. J Anim Sci. 2003;81:1040-1050.

32. Salem AZM, Kholif AE, Olivares M, Elghandour MMY, Mellado M, Arece J. Influence of S. babylonica extract on feed intake, growth performance and diet in vitro gas production profile in young lambs. Trop Anim Health Prod. 2014;46:213- 219.

33. Gado HM, Salem AZM, Odongo NE, Borhami BE. Influence of exogenous enzymes ensiled with orange pulp on digestion and growth performance in lambs. Anim Feed Sci Technol. 2011;165:131136.

34. Hristov AN, McAllister TA, Cheng KJ. Intraruminal supplementation with increasing levels of exogenous polysaccharide-degrading enzymes: effects on nutrient digestion in cattle fed a barley grain diet. J Anim Sci. 2000;78:477-87.

35. Salem AZM, El-Adawy M, Gado H, Camacho LM, González-Ronquillo M, Alsersy H, et al. EFFECTS OF EXOGENOUS ENZYMES ON NUTRIENTS DIGESTIBILITY AND GROWTH PERFORMANCE IN SHEEP AND GOATS [EFECTO. Trop Subtrop Agroecosystems [Internet]. 2011;14(3):867-74. Available from: http://www.redalyc.org/articulo.oa?id=93921493030 
36. Rufino LM de A, Detmann E, Gomes DÍ, dos Reis WLS, Batista ED, Filho S de CV, et al. Intake, digestibility and nitrogen utilization in cattle fed tropical forage and supplemented with protein in the rumen, abomasum, or both. J Anim Sci Biotechnol [Internet]. 2016;7(11):1-10. Available from: http://dx.doi.org/10.1186/s40104-016-0069-9

37. de Almeida AK, de Resende KT, da Silva SP, Soares D da C, Fernandes MHMR, Teixeira I. AMA. Protein requirements for growth in male and female Saanen goats. Rev Bras Zootec. 2015;44(11):397-404.

38. Elamin KM, Tamee Eldar AA, Amin AE, Abdalla FS, Hassan HE. Digestibility and nitrogen balance of Sudan goat ecotypes fed different energy/protein levels. Asian J Anim Sci. 2012;6(5):230-9.

39. Bastos MPV, Carvalho GGP De, Pires AJV, Silva RR, Filho AE, dos Santos EDJ, et al. Ingestive Behavior and Nitrogen Balance of Confined Santa Ines Lambs Fed Diets Containing Soybean Hulls. Asian-Australasian J Anim Sci [Internet]. 2014;27(1):24-9. Available from: http://dx.doi.org/10.5713/ajas.2013.13076 www.ajas.info

40. Endo V, Sobrinho AG da S, Almeida FA de, Lima NLL, Zeola NMBL. Digestibility and nitrogen balance of lambs fed sugarcane hydrolyzed under different conditions as roughage in the diet. Ciência Rural. 2015;45(2):304-10.

41. Jetana T, Vongpipatana C, Thongruay S, Usawang S, Sophon S. Apparent Digestibility , Nitrogen Balance, Ruminal Microbial Nitrogen Production and Blood Metabolites in Thai Brahman Cattle Fed a Basal Diet of Rice Straw and Supplemented with Some Tropical Protein-rich Trees. Asian J Anim Sci. 2010;23(4):465-74.

42. Pereira ES, Pimentel PG, Moreno GMB, Mizubuti IY, Ribeiro EL de A, Campos ACN, et al. Intake, nutrient digestibility and nitrogen balance in lactating dairy cows fed diets containing sunflower cake. 2012;33(6):2461-70. 